\title{
BEYOND OBVIOUS BEHAVIOR PATTERNS IN UNIVERSITIES: STUDENT ENGAGEMENT WITH THE UNIVERSITY
}

\author{
DOI: 10.17261/Pressacademia.2018.946 \\ RJBM- V.5-ISS.3-2018(5)-p.222-230
}

\author{
Alev Kocak Alan ${ }^{1}$, Ebru Tumer Kabadayi², Nilsah Cavdar ${ }^{3}$ \\ ${ }^{1}$ Gebze Technical University, Kocaeli, Turkey. \\ akocak@gtu.edu.tr, ORCID: 0000-0002-1060-1593 \\ ${ }^{2}$ Gebze Technical University, Kocaeli, Turkey. \\ tumer@gtu.edu.tr , ORCID: 0000-0002-0673-6866 \\ ${ }^{3}$ Gebze Technical University, Kocaeli, Turkey. \\ n.cavdar@gtu.edu.tr , ORCID: 0000-0003-0734-3930
}

Date Received: July 8, 2018

Date Accepted: September 12, 2018

To cite this document

Kocak Alan, A., Tumer Kabadayi, E., Cavdar, N. (2018). Beyond obvious behavior patterns in universities: student engagement with the university. Research Journal of Business and Management (RJBM), V.5(3), p.222-230.

Permemant link to this document: http://doi.org/10.17261/Pressacademia.2018.946

Copyright: Published by PressAcademia and limited licenced re-use rights only.

\section{ABSTRACT}

Purpose- This study aims to provide a model to help universities gain competitive advantage by analyzing the factors that influence student engagement with the university.

Methodology- Survey method was used to test the hypothesized effects in the proposed model and 432 people were surveyed. Survey results were analyzed by structural equation modelling.

Findings- As a result of the research, all hypothesized effects in the proposed model, a positive effect of university image on both positive emotions, and student satisfaction, a negative effect of it on negative emotions, a positive effect of positive emotions on student satisfaction, a negative effect of negative emotions on student satisfaction, and a positive effect of student satisfaction on student engagement with the university, were supported.

Conclusion- Emotions and satisfaction have the great importance in the emergence of student engagement with the university. Handling university image as a starting point in the study with the prediction that the university image is also important for students' engagement behavior is supported by significant results.

Keywords: Student engagement, student emotions, student satisfaction, university image.

JEL Codes: M30, M31, M39

\section{INTRODUCTION}

As in every institution, "customers" and their opinions have also great importance in the education sector. In this regard, for institutions offering higher education, student loyalty is very important (Helgesen and Nesset, 2007) and today, behaviors that go beyond loyalty or satisfaction, like customer engagement, need to be investigated. In today's competitive environment, there is a need for behavior in which stronger ties are established with organizations and that do not result in customers only as re-purchasing. That stronger effect refers to customer engagement (Pansari and Kumar, 2017) and in such a competitive environment for universities (Marič et al., 2010; Bringula and Basa, 2011), the issue is becoming increasingly important for these institutions as well.

To gain competitive advantage, universities should maintain or develop an attractive image (Parameswaran and Glowacka, 1995). In most cases, the image becomes much more important than the product or service itself in the decision making processes of the customers (Vigoda-Gadot et al., 2003). Starting from this point of view, the university image is handled as an environmental factor in this study, representing the starting point of the research, and engagement behaviors of students is examined through its effect on student emotions, student satisfaction, the effects of emotions and satisfaction on itself as well. The aim of the study is to examine the engagement behaviors of students and to present effective factors 
on that behavior. In this way, a model can be presented that includes effective factors on student engagement behaviors and provides information for universities to gain competitive advantage. Thus, innovative strategies will be offered to universities to strengthen engagement behaviors of their students.

The study will begin with a literature review and theoretical framework as a base of the predicted model. Then, the hypothesized effects will be explained with theoretical backgrounds. After that, sample, data collection, and information about measures will be provided. Lastly before conclusion and discussion, the information about analyses and results of them will take place.

\section{LITERATURE REVIEW}

\subsection{Customer Engagement}

Understanding consumers and explaining their behaviors is one of the important issues for both academicians and practitioners in the field of marketing. Pansari and Kumar (2017) highlight that scientific studies on different behavioral patterns of consumers have been carried out in this context for many years, but there is a need for a differentiation at this point. In this regard, customer engagement refers to the changing focus of the field from relationship marketing to gaining differentiation and long-lasting competitive advantage as a higher level of the constructs like profitable loyalty and satisfaction (Pansari and Kumar, 2017) and defined as "the level of a customer's cognitive, emotional and behavioral investment in specific brand interactions" (Hollebeek, 2011). Pansari and Kumar (2017) also explain how this structure differs from other behavioral patterns such as customer involvement, customer experience, customer satisfaction, customer loyalty, customer trust, customer commitment, customer brand value. For example, while customer satisfaction may result in only re-purchasing the product or service after the customer's positive experience, customer engagement will result in behaviors that can go beyond the purchases like giving feedbacks to the company, talking about the brand on social media etc.

In parallel with the evolution of customer engagement approach of Pansari and Kumar (2017), explaining the construct within the framework of emotion and satisfaction, customer engagement is handled as an extended approach in this study. Respecting that a fact occurring in the social environment will end up with an emotion on the individual and turn out to behavior as a response (Mehrabian and Russell, 1974), the research framework of the study, which is constituted with the combination of the dimensions, brand image as environmental stimuli (Bell, 1999), negative and positive emotions as emotional states, satisfaction as a response of individual and customer engagement as a higher level of satisfaction and ultimate response of individual, is as follows:

Figure 1: Research Model

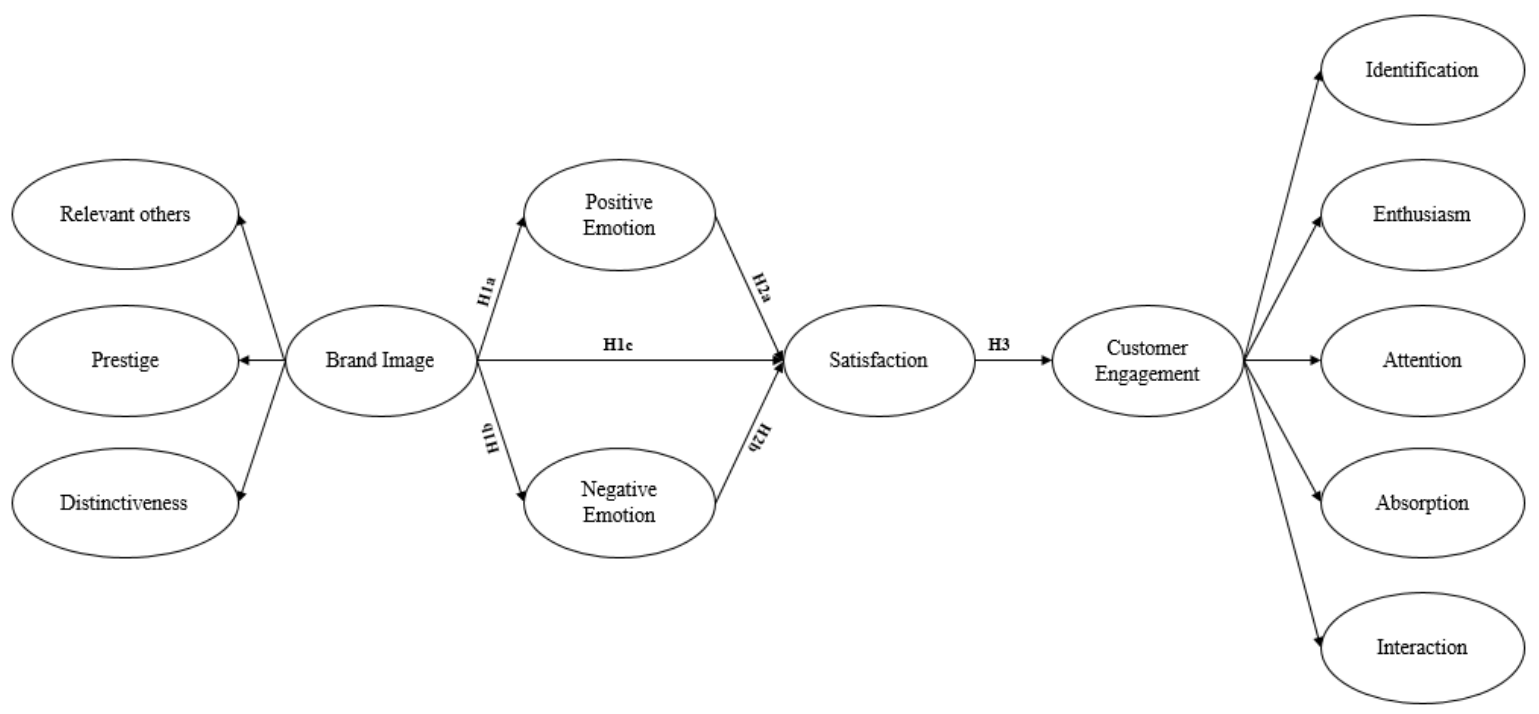

\subsection{Brand Image}

Along with the great importance of brand image for companies, the concept is also important for non-profit organizations (Marič et al., 2010). Universities can be an example for these institutions and university image constitutes a research focus for the field of marketing from day to day (i.e., Palacio et al., 2002; Wilkins and Huisman, 2013; Aghaz et al., 2015). To influence students and professors, especially to ensure that top students and professors prefer the university, to build 
student loyalty, to increase the competitiveness in the market can be seen as the reasons for a good university image representing also an important research topic (Sevier, 1994; Bush et al., 1998; Palacio et al., 2002; Arpan et al., 2003; Standifird, 2005; Duarte et al., 2010).

Several important factors have been used to explain the university image like the university's size, location, facilities, appearance, range of fields and courses, distinctiveness, commitment to academic prominence, national image of the university, climate, financial resources, diversity among students, the number of services provided by the university, image of studies conducted by university, overall image of the university, image of programs offered by the university, appearance, excellence of the faculty, extent of endowments, institution visibility, prestige, existence of family atmosphere, friendliness of students, extent of family-related values on university, interpersonal communication, quality of education, environmental factors, psychological environment etc. (Theus, 1993; Treadwell and Harrion, 1994, Kazoleas et al., 2001; Arpan et al., 2003). In order to better understand all these factors, more general approaches or categorizations can be helpful. Nguyen and LeBlanc (2001), for instance, hold the topic with two components, functional component, representing more tangible issues, and emotional component, including feelings and attitudes about the organization. In a similar classification, there is also two components to measure university image which are cognitive, representing the beliefs and affective, representing feelings (Palacio et al., 2002). In the context of this study, emotional side of university image concept is much more important as emotion represents an important construct of customer engagement (Pansari and Kumar, 2017).

University image is influential on various behaviors or situations that can be associated with the emotions of the people. Aghaz et al. (2015), for example, found that perceived university image has a significant effect on university competence, university reliability, and students' identification with their university. In a more general approach, if an individual perceives an organization as an attractive institution, he much more identifies with this organization (Dutton et al., 1994). Wilkins and Huisman (2013), on the other hand, provide a reliable scale including relevant others, prestige, and distinctiveness to measure university image but do not test the effect of university image-related factors on any behavioral outcomes of students. From starting this point of view, customer engagement concept is used as a consumer behavior and starting point of this concept, emotion and satisfaction (Pansari and Kumar, 2017), is handled as an outcome of brand image. Therefore, it is predicted that;

H1a: University image have positive effects on the arousal of positive emotions.

H1b: University image have negative effects on the arousal of negative emotions.

H1c: University image have positive effects on student satisfaction.

\subsection{Emotions}

Individuals are expected to give emotional reactions to environmental events (Mehrabian and Russell, 1974) and that effect can be seen in various contexts in the literature like marketing (e.g., Bagozzi et al., 1999), retailing (e.g., Gilboa et al., 2003), or more specifically customer purchase behavior (e.g., Westbrook, 1987), service experience (e.g., Ladhari, 2009), service satisfaction (e.g., Liljander and Strandvik, 1997) etc. In this regard, increasing the examples of the service sector-related studies is possible that it constitutes the context of the present study by handling universities as one of the fields representing this sector.

According to Pansari and Kumar (2017), customer emotions are important to constitute engagement towards the brand. Since the emotions of individuals are so powerful that can affect human behaviors, testing their effects for engagement is logical. Hollebeek (2013), for instance, suggests that emotions like high level of arousal also indicate high level of engagement. Blasco-Arcas (2016) also holds the emotions with the perspective of pleasure, arousal, and dominance and found that these experiences of customers positively influence their engagement with the firm. However, the concept was not addressed by the positive and negative emotional focus directly which can lead to different behavioral consequences (Chitturi, 2009). A similar effect can be measured in universities representing a service sector through their consumers', students', positive and negative emotions. Hence, it is hypothesized that;

H2a: Positive emotions have positive effects on student satisfaction.

H2b: Negative emotions have negative effects on student satisfaction.

\subsection{Satisfaction}

After the consumers experience a product or service, they may make an assessment of their experience. These evaluations represent the overall feelings or attitudes of them which may result in satisfaction or dissatisfaction (Solomon et al., 2012). Achieving satisfied customers can be important for any organization. For universities, for instance, the satisfaction of the students means that they have to be in helpful behaviors for the university such as recommending programs in the 
university to others, being employers of graduates from the university, continuing their educations as postgraduates in the same university, donating to the university consistently (Guolla, 2001).

One of the key constructs of customer engagement recommended by Pansari and Kumar (2017) is customer satisfaction. In university-student context, this construct can be much more important because being satisfied with the university will not result in a profitable situation like re-purchasing directly. Behaviors beyond the re-purchase, which are important outcomes of the customer engagement structure that Pansari and Kumar (2017) highlight, are needed in university-student relationship. Students make a subjective evaluation of their experience like their educations or campus life (Elliott and Healy, 2001; Elliott and Shin, 2002). If the satisfaction arises in students as a result of these evaluations, it is expected that the satisfaction of the students from their universities will constitute an engagement towards the universities like in the context of online games (Cheung et al., 2015), retail banking (Giannakis-Bompolis and Boutsouki, 2014), financial services (Cambra-Fierro et al., 2016), mobile phone sector (Cambra-Fierro et al., 2013). Thus, the following hypothesis is proposed:

H3: Student satisfaction have positive effects on their engagement with the university.

\section{DATA AND METHODOLOGY}

\subsection{Sample and Data Collection}

In order to reach a representative sample from the entire customer population, non-probability convenience sampling technique (Krathwohl, 1997) was used in the present study. The questionnaire was prepared online and survey link was shared through online communication channels like e-mail, social media platforms, online messaging applications, Internet forums etc. These sharing processes were made so as to be accessible to all university students in Turkey. With this system, 30 people were surveyed firstly. After the evaluation of pre-test results, any problem about research instrument was not seen and then, the survey reached 432 respondents. Demographic information related to the sample of pre-test is presented in Table 1.

Table 1: Demographic Characteristics of Sample

\begin{tabular}{|l|l|l|}
\hline Characteristics & $\mathbf{N}$ & $\mathbf{\%}$ \\
\hline Gender & & \\
\hline Female & 273 & 63.19 \\
\hline Male & 159 & 36.81 \\
\hline Age & & \\
\hline $18-24$ & 354 & 81.9 \\
\hline $25-34$ & 72 & 16.7 \\
\hline $35-44$ & 6 & 1.4 \\
\hline Education level & & \\
\hline Undergraduate & 397 & 91.9 \\
\hline Master's & 22 & 5.1 \\
\hline PhD & 13 & 3 \\
\hline
\end{tabular}

\subsection{Measures}

To test the hypotheses, multi-item scales were adapted from the extant literature. The items of these five-point Likert scales with anchors 1 for strongly disagree and 5 for strongly agree are shown in Table 2. Relevant others and prestige dimensions of brand image were measured with adapted scales from the study of Wilkins and Huisman (2013), and the scale of distinctiveness dimension was adapted from Mohd Yasin, Nasser Noor, and Mohamad (2007). Positive and negative emotions scales proposed by Jani and Han (2013) were used in this study. To measure satisfaction, the scale of Flavián, Guinalíu, and Gurrea (2006) was adapted to the context of this study. Customer engagement can be handled and measured in various ways. That behavior is sometimes regarded as a first-order (i.e. Giannakis-Bompolis and 2014, Islam and Rahman, 2016) and sometimes a second-order (i.e. Thakur, 2016, So et al., 2012) construct in different contexts. To achieve a more comprehensive measurement, a more detailed second-order structure with more detailed items and dimensions has been adopted within this study. In the context of this research, customer engagement represents an umbrella concept including identification, enthusiasm, attention, absorption, and social media interaction of students toward their universities. The customer engagement scale in the study of So, King, and Sparks (2014) was utilized for the measurement of the dependent variable of this study. All items were adapted with back to back translation method, translating the original items in English language to Turkish first, then to English again by another researcher, and lastly evaluating English versions (original and translation) by three academicians from the field of marketing. After this intensive translation process, research instrument has become final version. 


\section{FINDINGS}

\subsection{Measure Assessments}

A hierarchical confirmatory factor analysis, including positive emotions, negative emotions, and satisfaction as first-order factors and university image, and student engagement as second-order factors, was conducted in keeping with two step approach of Anderson and Gerbing (1988). Factor loading and reliability estimates of each construct were shown in Table 2. As it can be seen in the table, composite reliability scores and Cronbach's alpha estimates indicate that the measures have reasonable reliability (Fornell and Larcker, 1981; Nunally, 1978). As an evidence for convergent validity, it can be seen that factor loadings are large and significant enough. The average variance-extracted estimates and the comparison of these estimates with squared correlations between the constructs show discriminant validities of measures (Fornell and Larcker, 1981). Moreover, the model fits the observed data well.

Table 2: Factor Loadings and Reliability Scores

\begin{tabular}{|c|c|c|c|c|}
\hline Construct & $\begin{array}{l}\text { Standardized } \\
\text { Loadings }\end{array}$ & $\begin{array}{l}\text { Cronbach's } \\
\text { Alpha }\end{array}$ & AVE & CR \\
\hline University Image & & .89 & .84 & .94 \\
\hline Relevant Others & & .81 & .69 & .82 \\
\hline Students in my school think highly of the university. & $.85^{* * *}$ & & & \\
\hline The university gets mainly positive coverage in the media. & $.81^{* * *}$ & & & \\
\hline Prestige & & .90 & .75 & .90 \\
\hline The university is a top university in its home country. & $.85^{* * *}$ & & & \\
\hline The university achieves high positions in rankings. & $.90^{* * *}$ & & & \\
\hline Employers like to recruit this university's graduates. & $.84^{* * *}$ & & & \\
\hline Brand Distinctiveness & & .95 & .72 & .95 \\
\hline I associate this university with dynamism. & $.83^{* * *}$ & & & \\
\hline I associate this university with high technology. & $.81^{* * *}$ & & & \\
\hline I associate this university with innovativeness. & $.85^{* * *}$ & & & \\
\hline I associate this university with sophistication. & $.88^{* * *}$ & & & \\
\hline I associate this university with distinctiveness. & $.86^{* * *}$ & & & \\
\hline I associate this university with excellence. & $.88^{* * *}$ & & & \\
\hline I associate this university with prestige. & $.83^{* * *}$ & & & \\
\hline Positive Emotion & & .95 & .76 & .95 \\
\hline Happy & $.89^{* * *}$ & & & \\
\hline Proud & $.85^{* * *}$ & & & \\
\hline Pleased & $.92^{* * *}$ & & & \\
\hline Contented & $.91^{* * *}$ & & & \\
\hline Peaceful & $.81^{* * *}$ & & & \\
\hline Excited & $.83^{* * *}$ & & & \\
\hline Negative Emotion & & .88 & .66 & .88 \\
\hline Angry & $.80^{* * *}$ & & & \\
\hline Shameful & $.73^{* * *}$ & & & \\
\hline Upset & $.92^{* * *}$ & & & \\
\hline Worrisome & $.78^{* * *}$ & & & \\
\hline Satisfaction & & .93 & .78 & .94 \\
\hline I think that I made the correct decision to choose this university. & $.88^{* * *}$ & & & \\
\hline $\begin{array}{l}\text { The experience that I have had with this university has been } \\
\text { satisfactory. }\end{array}$ & $.84^{* * *}$ & & & \\
\hline $\begin{array}{l}\text { In general terms, I am satisfied with what that this university has } \\
\text { provided me. }\end{array}$ & $.92^{* * *}$ & & & \\
\hline $\begin{array}{l}\text { In general, I am satisfied with the service I have received from } \\
\text { the university. }\end{array}$ & $.90^{* * *}$ & & & \\
\hline Student Engagement & & .91 & .70 & .92 \\
\hline Identification & & .86 & .60 & .86 \\
\hline $\begin{array}{l}\text { When someone praises this university, it feels like a personal } \\
\text { compliment. }\end{array}$ & $.76^{* * *}$ & & & \\
\hline
\end{tabular}




\begin{tabular}{|c|c|c|c|c|}
\hline $\begin{array}{l}\text { When I talk about this university, I usually say we rather than } \\
\text { they. }\end{array}$ & $.76^{* * *}$ & & & \\
\hline This university's successes are my successes. & $.81^{* * *}$ & & & \\
\hline $\begin{array}{l}\text { When someone criticizes this university, it feels like a personal } \\
\text { insult. }\end{array}$ & $.77^{* * *}$ & & & \\
\hline Enthusiasm & & .93 & .74 & .93 \\
\hline $\begin{array}{l}\text { I spend a lot of my discretionary time thinking about this } \\
\text { university. }\end{array}$ & $.81^{* * *}$ & & & \\
\hline I am passionate about this university. & $.89^{* * *}$ & & & \\
\hline I am enthusiastic about this university. & $.90^{* * *}$ & & & \\
\hline I am heavily into this university. & $.77^{* * *}$ & & & \\
\hline I feel excited about this university. & $.92^{* * *}$ & & & \\
\hline Attention & & .95 & .77 & .95 \\
\hline I like to learn more about this university. & $.83^{* * *}$ & & & \\
\hline I pay a lot of attention to anything about this university. & $.87^{* * *}$ & & & \\
\hline Anything related to this university grabs my attention. & $.86^{* * *}$ & & & \\
\hline I concentrate a lot on this university. & $.93^{* * *}$ & & & \\
\hline I spend a lot of time thinking about this university. & $.87^{* * *}$ & & & \\
\hline I focus a great deal of attention on this university. & $.91^{* * *}$ & & & \\
\hline Absorption & & .95 & .77 & .95 \\
\hline $\begin{array}{l}\text { When I am interacting with the university, I forget everything } \\
\text { else around me. }\end{array}$ & $.89^{* * *}$ & & & \\
\hline Time flies when I am interacting with the university. & $.91^{* * *}$ & & & \\
\hline When I am interacting with university, I get carried away. & $.90^{* * *}$ & & & \\
\hline $\begin{array}{l}\text { When interacting with the university, it is difficult to detach } \\
\text { myself. }\end{array}$ & $.88^{* * *}$ & & & \\
\hline In my interaction with the university, I am immersed. & $.89^{* * *}$ & & & \\
\hline When interacting with the university intensely, I feel happy. & $.80^{* * *}$ & & & \\
\hline Interaction & & .94 & .82 & .95 \\
\hline $\begin{array}{l}\text { I am someone who enjoys interacting with like-minded others in } \\
\text { the university's social networks. }\end{array}$ & $.81^{* * *}$ & & & \\
\hline $\begin{array}{l}\text { I am someone who likes actively participating in discussions in } \\
\text { the university's social networks. }\end{array}$ & $.94^{* * *}$ & & & \\
\hline $\begin{array}{l}\text { In general, I thoroughly enjoy exchanging ideas with other } \\
\text { people in the university's social networks. }\end{array}$ & $.94^{* * *}$ & & & \\
\hline $\begin{array}{l}\text { I often participate in conversations of the university's social } \\
\text { networks. }\end{array}$ & $.92^{* * *}$ & & & \\
\hline
\end{tabular}

CCR composite construct reliability. $X^{2}=3371.51(d f=1206), p<.001 ; X^{2} / d f=2.80$; comparative fit index $(\mathrm{CFI})=.91$; incremental fit index $(\mathrm{IFI})=.91$; Tucker-Lewis index $(\mathrm{TLI})=.90$; The Parsimonious Normed fit index $(\mathrm{PNFI})=.79$ and root mean squares error approximation (RMSEA) $=.06, * * * p<.001$

\subsection{Hypothesis Testing}

To test the proposed model, structural equation modelling (SEM) was used through AMOS 21. As a first step, descriptive statistics and intercorrelations across the five constructs were analyzed. Significant values which are in the expected direction can be seen in Table 3.

Table 3: Descriptive Statistics and Correlation Estimates

\begin{tabular}{|ll|l|l|l|l|l|l|l|}
\hline & Mean & SD & $\mathbf{1}$ & $\mathbf{2}$ & $\mathbf{3}$ & $\mathbf{4}$ & $\mathbf{5}$ \\
\hline 1. & University Image & 2.8893 & 1.09347 & $(.92)$ & & & & \\
\hline 2. & Positive Emotions & 3.1454 & 1.17616 & $.634^{* *}$ & $(.87)$ & & & \\
\hline 3. & Negative Emotions & 2.3374 & 1.12206 & $-.239^{* *}$ & $-.391^{* *}$ & $(.81)$ & & \\
\hline 4. & Student Satisfaction & 3.0885 & 1.23423 & $.696^{* *}$ & $.832^{* *}$ & $-.403^{* *}$ & $(.88)$ & \\
\hline 5. Student Engagement & 2.6263 & 0.98958 & $.648^{* *}$ & $.756^{* *}$ & $-.264^{* *}$ & $.723^{* *}$ & $(.84)$ \\
\hline
\end{tabular}

${ }^{* *}$ Correlation is significant at $p<.01$ (2-tailed) 
Research model with the path coefficients of the hypotheses was presented in Figure 2 . The model fits the observed data $\left(X^{2}=3387.03 ; X^{2} / d f=2.81 ; \mathrm{CFI}=0.91 ; \mathrm{IFI}=0.91 ; \mathrm{TLI}=0.90 ; \mathrm{PNFI}=0.79 ; \mathrm{RMSEA}=0.06,{ }^{*} p<0.05 ;{ }^{* *} p<0.01 ;{ }^{* * *} p<\right.$ $0.001)$. Besides, the model with acceptance of all hypotheses explains an important proportion of variability in student engagement (71\%).

Figure 2: Structural Equation Model with Parameter Estimates

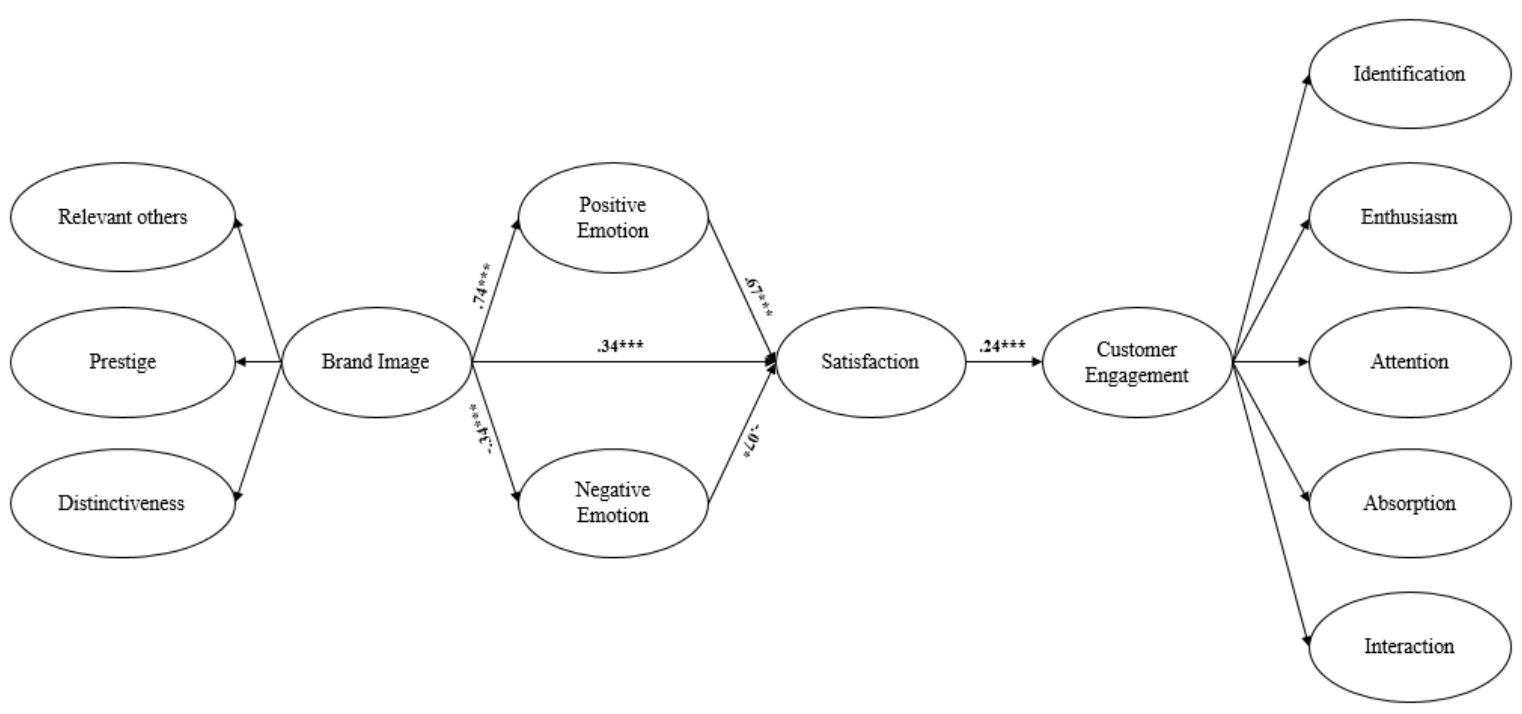

All hypotheses in the research were supported by the statistical tests, $\mathrm{H} 1 \mathrm{a}$ which hypothesizes a positive effect of university image on positive emotion ( $\beta$, standardized path coefficient $=0.74 ; t=14.38 ; p<0.001), \mathrm{H} 1 \mathrm{~b}$ predicts a negative effect of university image on negative emotion $(\beta=-0.34 ; t=-6.19 ; p<0.001), H 1 c$ predicts a positive effect of university image on student satisfaction $(\beta=0.34 ; \mathrm{t}=7.40 ; \mathrm{p}<0.001), \mathrm{H} 2 \mathrm{a}$ hypothesizes a positive effect of positive emotion on student satisfaction $(\beta=0.67 ; t=14.37 ; p<0.001), H 2 b$ predicts a negative effect of negative emotion on student satisfaction $(\beta=-$ $0.07 ; \mathrm{t}=-2.17 ; \mathrm{p}<0.05), \mathrm{H} 3$ hypothesizes a positive effect of student satisfaction on student engagement with the university $(\beta=0.24 ; t=5.60 ; p<0.001)$.

\section{Structural Parameter Estimates}

\begin{tabular}{|l|l|l|l|l|}
\hline Hypotheses & Path & Standardized Estimates & $\boldsymbol{t}$ value & Results \\
\hline H1a & University Image $\rightarrow$ Positive Emotions & .74 & $14.38^{* * *}$ & Supported \\
\hline H1b & University Image $\rightarrow$ Negative Emotions & -.34 & $-6.19^{* * *}$ & Supported \\
\hline H1c & University Image $\rightarrow$ Student Satisfaction & .34 & $7.40^{* * *}$ & Supported \\
\hline H2a & Positive Emotions $\rightarrow$ Student Satisfaction & .67 & $14.37^{* * *}$ & Supported \\
\hline H2b & Negative Emotions $\rightarrow$ Student Satisfaction & -.07 & $-2.17^{*}$ & Supported \\
\hline H3 & Student Satisfaction $\rightarrow$ Student Engagement & .24 & $5.60^{* * *}$ & Supported \\
\hline
\end{tabular}

\section{DISCUSSIONS AND CONCLUSION}

Considering the findings of the analyses in the research, significant results supporting all hypotheses were obtained. In this regard, significant empirical results in accordance with the suggestion of Pansari and Kumar (2017) were provided. It was seen that emotions and satisfaction have the great importance in the emergence of customer engagement in the context of student-university relationship. An important originality of the study is handling emotions in the context of both positive and negative emotions. The inclusion of university image to research models with the prediction that the university image is also important for students' engagement behavior is supported by significant results. The study from this aspect, provides evidence to the importance of university image (Wilkins and Huisman, 2013; Aghaz et al., 2015).

This study presents an empirically tested model of engagement, which is a strong behavior of customers, for universities in order to be able to gain competitive advantage. In this context, it is seen how important the university image is. At the same time, the prospects of various emotions to be awakened in the students have been proven. Besides, it is understood that satisfaction of students may cause them to do something for the university, and at this point there is no limit in what students can do for their universities like giving feedbacks to the university, talking about the university on social media etc. (Pansari and Kumar, 2017). Establishing such strong ties with students is a must for universities. In order to achieve this, 
adopting various innovative strategies to university context is possible. For example, in a world -in also universities- where information technology has developed so much (Marič et al., 2010), transforming the competition created by this situation to an opportunity for the institutions is also possible. Mobile applications in relation with education and training that can be used in an integrated way in lessons, edutainment implementations for students, effective social media programs that can be used for the introduction of the university etc. can be given as the examples for innovative tools which can be used by universities. Universities can also carry out various projects to increase their brand image. In this regard, beneficial projects for the society, the environment in which the university is in service, businesses operating in the same field as their faculties can be conducted by the teams including both students and academicians. Thus, the visibility of the universities will increase and they can also promote the success of their students and the academic power of their employees arising from successful projects to the society.

Besides significant contributions of this study, it has also some limitations and through solutions for this limitations, it can be moved forward academically by addressing these issues. For instance, conducting the research on different faculties or units in a university is possible and in this way, the difference between these faculties/units can be analyzed. On the other hand, with a larger and representative sample, the engagement behaviors of students from the universities in different regions of the country can be compared. It may also focus on what may be the consequences of students' engagement with their universities and thus, the research model of this study can be extended. Another important limitation of the study is that students from all universities in the country cannot be reached. It is also possible to carry out a research focusing on this constraint and reaching thoughts of students in all universities or at least one university from each region.

\section{REFERENCES}

Aghaz, A., Hashemi, A., Sharifi Atashgah, M. S. (2015). Factors contributing to university image: the postgraduate students' points of view. Journal of Marketing for Higher Education, 25(1), 104-126.

Anderson, J. C., Gerbing, D. W. (1988). Structural equation modeling in practice: a review and recommended two-step approach. Psychological bulletin, 103(3), 411.

Arpan, L. M., Raney, A. A., Zivnuska, S. (2003). A cognitive approach to understanding university image. Corporate Communications: An International Journal, 8(2), 97-113.

Bagozzi, R. P., Gopinath, M., Nyer, P. U. (1999). The role of emotions in marketing. Journal of the academy of marketing science, 27(2), 184206 .

Bell, S. J. (1999). Image and consumer attraction to intraurban retail areas: an environmental psychology approach. Journal of Retailing and Consumer services, 6(2), 67-78.

Blasco-Arcas, L., Hernandez-Ortega, B. I., Jimenez-Martinez, J. (2016). Engagement platforms: the role of emotions in fostering customer engagement and brand image in interactive media. Journal of Service Theory and Practice, 26(5), 559-589.

Bringula, R. P., Basa, R. S. (2011). Institutional image indicators of three universities: basis for attracting prospective entrants. Educational Research for Policy and Practice, 10(1), 53-72.

Bush, V., Ferrell, O. C., Thomas Jr, J. L. (1998). Marketing the business school: an exploratory investigation. Journal of Marketing Education, 20(1), 16-23.

Cambra-Fierro, J., Melero-Polo, I., Sese, F. J. (2016). Can complaint-handling efforts promote customer engagement?. Service Business, 10(4), 847-866.

Cambra-Fierro, J. J., Melero-Polo, I., Vázquez-Carrasco, R. (2013). Customer engagement: Innovation in non-technical marketing processes. Innovation, 15(3), 326-336.

Cheung, C. M., Shen, X. L., Lee, Z. W., Chan, T. K. (2015). Promoting sales of online games through customer engagement. Electronic Commerce Research and Applications, 14(4), 241-250.

Chitturi, R. (2009). Emotions by design: a consumer perspective. International Journal of Design, 3(2).

Duarte, P. O., Alves, H. B., Raposo, M. B. (2010). Understanding university image: a structural equation model approach. International Review on Public and Nonprofit Marketing, 7(1), 21-36.

Fornell, C., Larcker, D. F. (1981). Evaluating structural equation models with unobservable variables and measurement error. Journal of marketing research, 39-50.

Giannakis-Bompolis, C., Boutsouki, C. (2014). Customer relationship management in the era of social web and social customer: an investigation of customer engagement in the Greek retail banking sector. Procedia-Social and Behavioral Sciences, 148, 67-78.

Gilboa, S., Rafaeli, A. (2003). Store environment, emotions and approach behaviour: applying environmental aesthetics to retailing. The International Review of Retail, Distribution and Consumer Research, 13(2), 195-211. 
Guolla, M. (1999). Assessing the teaching quality to student satisfaction relationship: applied customer satisfaction research in the classroom. Journal of marketing theory and practice, 7(3), 87-97.

Helgesen, $\varnothing$., Nesset, E. (2007). Images, satisfaction and antecedents: drivers of student loyalty? A case study of a Norwegian university college. Corporate Reputation Review, 10(1), 38-59.

Hollebeek, L. (2011). Exploring customer brand engagement: definition and themes. Journal of strategic Marketing, 19(7), 555-573.

Hollebeek, L. D. (2013). The customer engagement/value interface: an exploratory investigation. Australasian Marketing Journal (AMJ), 21(1), 17-24.

Islam, J. U., Rahman, Z. (2016). Linking customer engagement to trust and word-of-mouth on Facebook brand communities: an empirical study. Journal of Internet Commerce, 15(1), 40-58.

Jani, D., Han, H. (2013). Personality, social comparison, consumption emotions, satisfaction, and behavioral intentions: how do these and other factors relate in a hotel setting?. International Journal of Contemporary Hospitality Management, 25(7), 970-993.

Kazoleas, D., Kim, Y., Anne Moffitt, M. (2001). Institutional image: a case study. Corporate Communications: an international journal, 6(4), 205-216.

Krathwohl, D. (1997). Methods of educational and social science research: an integrated approach (2nd ed.). Glen View, IL: Addison Wesley Longman.

Liljander, V., Strandvik, T. (1997). Emotions in service satisfaction. International Journal of service industry management, 8(2), $148-169$.

Marič, M., Pavlin, J., Ferjan, M. (2010). Educational institution's image: a case study. Organizacija, 43(2), 58-65.

Mazaheri, E., Richard, M. O., Laroche, M., Ueltschy, L. C. (2014). The influence of culture, emotions, intangibility, and atmospheric cues on online behavior. Journal of Business Research, 67(3), 253-259.

Mohd Yasin, N., Nasser Noor, M., Mohamad, O. (2007). Does image of country-of-origin matter to brand equity?. Journal of Product \& brand management, 16(1), 38-48.

Mehrabian, A., Russell, J. A. (1974). An approach to environmental psychology. the MIT Press.

Nguyen, N., LeBlanc, G. (2001). Image and reputation of higher education institutions in students' retention decisions. International Journal of Educational Management, 15(6), 303-311.

Nunally, J. C. (1978). Psychometric theory, 2nd edn. McGraw-Hill, New York.

Palacio, A., Díaz Meneses, G., Pérez Pérez, P. J. (2002). The configuration of the university image and its relationship with the satisfaction of students. Journal of Educational administration, 40(5), 486-505.

Pansari, A., Kumar, V. (2017). Customer engagement: the construct, antecedents, and consequences. Journal of the Academy of Marketing Science, 45(3), 294-311.

Parameswaran, R., Glowacka, A. E. (1995). University image: an information processing perspective. Journal of Marketing for HIGHER EDUCATION, 6(2), 41-56.

Sevier, R. A. (1994). Image is everything--strategies for measuring, changing, and maintaining your institution's image. College and University, 69(2), 60-75.

Standifird, S. S. (2005). Reputation among peer academic institutions: an investigation of the US news and world report's rankings. Corporate Reputation Review, 8(3), 233-244.

So, K. K. F., King, C., Sparks, B. (2014). Customer engagement with tourism brands: scale development and validation. Journal of Hospitality \& Tourism Research, 38(3), 304-329.

Solomon, M., Russell-Bennett, R., Previte, J. (2012). Consumer behaviour. Pearson Higher Education AU.

Thakur, R. (2016). Understanding customer engagement and loyalty: a case of mobile devices for shopping. Journal of Retailing and Consumer Services, 32, 151-163.

Theus, K. T. (1993). Academic reputations: the process of formation and decay. Public Relations Review, $19(3), 277-291$.

Treadwell, D. F., Harrison, T. M. (1994). Conceptualizing and assessing organizational image: model images, commitment, and communication. Communications Monographs, 61(1), 63-85.

Vigoda-Gadot, E., Vinarski-Peretz, H., Ben-Zion, E. (2003). Politics and image in the organizational landscape: an empirical examination among public sector employees. Journal of Managerial Psychology, 18(8), 764-787.

Wilkins, S., Huisman, J. (2013). Student evaluation of university image attractiveness and its impact on student attachment to international branch campuses. Journal of Studies in International Education, 17(5), 607-623. 